\title{
The nature and drivers of contracts in cattle herding and management: The case of Ghana
}

\author{
Godwin Yao Ameleke ${ }^{1,2^{*}}$ (D), Rein Haagsma', Naaminong Karbo² and Akwasi Mensah-Bonsu ${ }^{3}$
}

\begin{abstract}
We study the characteristics of contracts in cattle production in Ghana and explain variations in contract type using agency and transaction cost theory. In their study of pastoral groups, especially those in West Africa, anthropologists have distinguished between two categories of contracts in cattle production: cattle owner-herd manager contracts and herd manager-herdsman contracts. However, few studies have analysed the variations in contract type within each category. Using survey data from 342 cattle kraal owners, we explored the contract types under the two contract categories and analysed their drivers using crosstabulations. Contract types in each category can be explicit, with the reward given by the principal explicitly specified, or implicit and unspecified. Environmental uncertainty was associated with implicit contracts while for explicit contracts, kraal owners' outside options or opportunity cost for monitoring was associated with fixed-wage contracts, subsidy-only contracts, and input contribution by kraal owners. The combination of moral hazard and measurement costs explained whether herdsmen were familial and not paid with milk or hired and paid with milk. Our findings provide further insights into the drivers of contract type.
\end{abstract}

Keywords: Cattle production, Cattle herding, Pastoralism, Contract, Transaction cost, Agency theory, Africa

\section{Introduction}

Contracts in agricultural production are important worldwide. For the parties involved, contracts may provide incentives that influence productivity and investment decisions. Productivity may be indicated by crop output per hectare of land, average daily weight gain of livestock per kilogramme of feed intake, or daily milk yield per animal. Investment decisions comprise land improvement, tree planting, pasture cultivation, construction of wells and dams, acquisition of farm houses, and farm equipment. In Sub-Saharan Africa, contracts are used both in crop production and livestock production. Crop production contracts, which often include land rental or land

\footnotetext{
* Correspondence: gameleke@hotmail.com

'Development Economics Group, Wageningen University, Hollandesweg 1, 6706 KN Wageningen, the Netherlands

${ }^{2}$ Council for Scientific \& Industrial Research (CSIR) - Animal Research Institute, P.O. Box AH20, Accra, Ghana

Full list of author information is available at the end of the article
}

tenancy contracts, usually occur as sharecropping, fixed land rental, or fixed-wage contracts between a landlord and a tenant (Ackerberg and Botticini 2002; Eswaran and Kotwal 1985; Laffont and Matoussi 1995; Sen 2011). Livestock production contracts frequently occur as arrangements between livestock owners and herdsmen, and between livestock owners doubling as herd managers and other livestock owners.

Generally, three sets of studies have been conducted regarding contracts in crop production. The first set of studies is theoretical studies that explain why different contract types exist (Stiglitz 1974; Newbery 1977; Hallagan 1978; Allen 1985; Reid 1976; Eswaran and Kotwal 1985; Muthoo 1998; Basu 1992; Sen 2011; Ghatak and Pandey 2000). The second set of studies investigates the influence of contracts on productivity in crop production (Laffont and Matoussi 1995; Jacoby and Mansuri 2009; Jahnke 1982; Shaban 1987). The third set of 
studies investigates links between contracts (or land use rights) and land improvement decisions in crop production (Abdulai et al. 2011; Goldstein and Udry 2008; Zhang and Owiredu 2007; Place and Hazell 1993).

In livestock production in Sub-Saharan Africa, knowledge on contracts has mainly come out of studies on pastoralists. Studies on West Africa have focused on herding arrangements among the Fulbe (Fulani) pastoralists of the semi-arid agro-climatic zone (Turner 2009; Turner and Hiernaux 2008; van Driel 1999; Dijk 1994; Bassett 1994; Moritz et al. 2011; Moritz et al. 2015). Knowledge on herding contracts in the region emanates from the study of four main issues: the link between herding arrangements and range management and the environment; the shift in ownership of livestock from pastoralists to other people, and its effect on rangeland productivity (Turner and Hiernaux 2008; Turner 2009; Toulmin 1992); conflicts between herdsmen and farmers (Bassett 1994; Tonah 2003, 2006; Moritz 2010); and the link between livestock transfers and social security (Dijk 1994).

Relatively little research exists on contracts in livestock production regarding why some contract types are chosen over others, especially in relation to the implications this has for livestock productivity and investment. Some explanation for the choice of one contract type over another has been provided by Binswanger and McIntire (1987). They explain cattle entrustment in semi-arid, land-abundant areas, where a cattle owner entrusts his cattle into the care of another person, in terms of two factors. First is the need for transhumance. The cattle owner usually is a crop farmer too. He prefers to stay at home to cultivate his land, while others herd his cattle in distant lands in search of pasture. Second is the economies of scale in herding larger numbers of animals. It makes a cattle owner willing to take the herds of his neighbours alongside his own to the grazing field in return for some reward. Based on these two factors, Binswanger and McIntire (1987) predict how cattle entrustment will change as population density, external migration, and trade increase. Another, more recent, contribution by Tadesse et al. (2016) shows that cattle sharing and rental contracts in Ethiopia are a response to imperfect credit and insurance services. Since contract type influences resource allocation and thereby productivity, more research could help improve our understanding of why various types occur, especially under sedentary herding in the sub-humid zone in SubSaharan Africa including Ghana.

Also, studies on pastoralism in West Africa have tended to focus mainly on contracts between a herdsman and a kraal owner (Bassett 1994; Tonah 2003, 2006). Yet, often the kraal owner, as a cattle owner himself, is an intermediary between his herdsmen and one or more cattle owners who have animals in his kraal.
Here, the functions of a kraal owner are the same as those of a herd patriarch in Turner (1999), a herd manager in Turner and Hiernaux (2008), and an independent pastoralist and intermediary in Moritz et al. (2011). ${ }^{1}$ Following Turner (1999), Turner and Hiernaux (2008), and Moritz et al. (2011), we highlight the distinction between kraal owner-herdsman contracts and cattle owner-kraal owner contracts, since these involve different sets of contractual arrangements that provide different sets of rules and incentives to the parties. Besides, different factors could be at play in defining the arrangements. For instance, risk aversion may influence the choice of contract type between the cattle owner and the kraal owner to a greater degree than between the kraal owner and the herdsman.

The following questions arise. First, what are the types of contracts in cattle production in Ghana, drawing a distinction between the rights and obligations of herdsmen versus kraal owners and those of cattle owners versus kraal owners? Second, how can we explain the prevailing variations in contract type using contract theory? To address these questions, we sampled 342 cattle kraals and interviewed kraal owners, other cattle owners keeping cattle in the kraal, and a herdsman taking care of cattle in the kraal. Using the data collected, we explored the contract types under the two contract categories and analysed their drivers using crosstabulations. It was found that contract types in each category could be explicit, with the reward given by the principal explicitly specified, or implicit and unspecified. Environmental uncertainty was associated with implicit contracts while for explicit contracts, kraal owners' outside options or opportunity cost of monitoring was associated with fixed-wage contracts, subsidy-only contracts, and input contribution by kraal owners. The combination of moral hazard and measurement costs explained whether a herdsman was familial and not paid with milk or hired and paid with milk. Our findings provide further insights into the drivers of contract type.

The rest of this paper is structured as follows. The "The study area" section provides an overview of the study area and cattle production in Ghana. The "Agricultural contract types and drivers" section provides the conceptual framework of this study and reviews the major contract theories. The "Methodology" section presents the methodology underlying the data collection. The "Results" section presents the results of our surveys, and the "Discussions" section discusses them. The "Conclusion" section concludes.

\footnotetext{
${ }^{1}$ We view the kraal owner, herd patriarch, and herd manager as the same when they serve as intermediaries between another cattle owner and a herdsman.
} 


\section{The study area}

Ghana, a country in West Africa, lies between latitudes $4^{\circ} \mathrm{N}$ and $12^{\circ} \mathrm{N}$ and longitudes $4^{\circ} \mathrm{W}$ and $2^{\circ} \mathrm{E}$. It is in the sub-humid agro-climatic zone. Cattle production occurs mainly in the Guinea savannah, Sudan savannah, and Coastal savannah, though the forest to savannah Transitional zone is becoming increasingly important for cattle production (Fig. 1). The Guinea savannah zone corresponds approximately to three administrative regions in the north of Ghana: Upper West Region, Northern Region, and Upper East Region. The Sudan savannah zone is a relatively small area in the north-east corner of the Upper East Region. The Coastal savannah stretches across three regions: Central Region, Greater Accra Region, and Volta Region, and is boarded to the south by the sea, the Gulf of Guinea in the Atlantic Ocean. The Transitional zone comprises mainly the Brong-Ahafo Region, but portions of it are the northern parts of

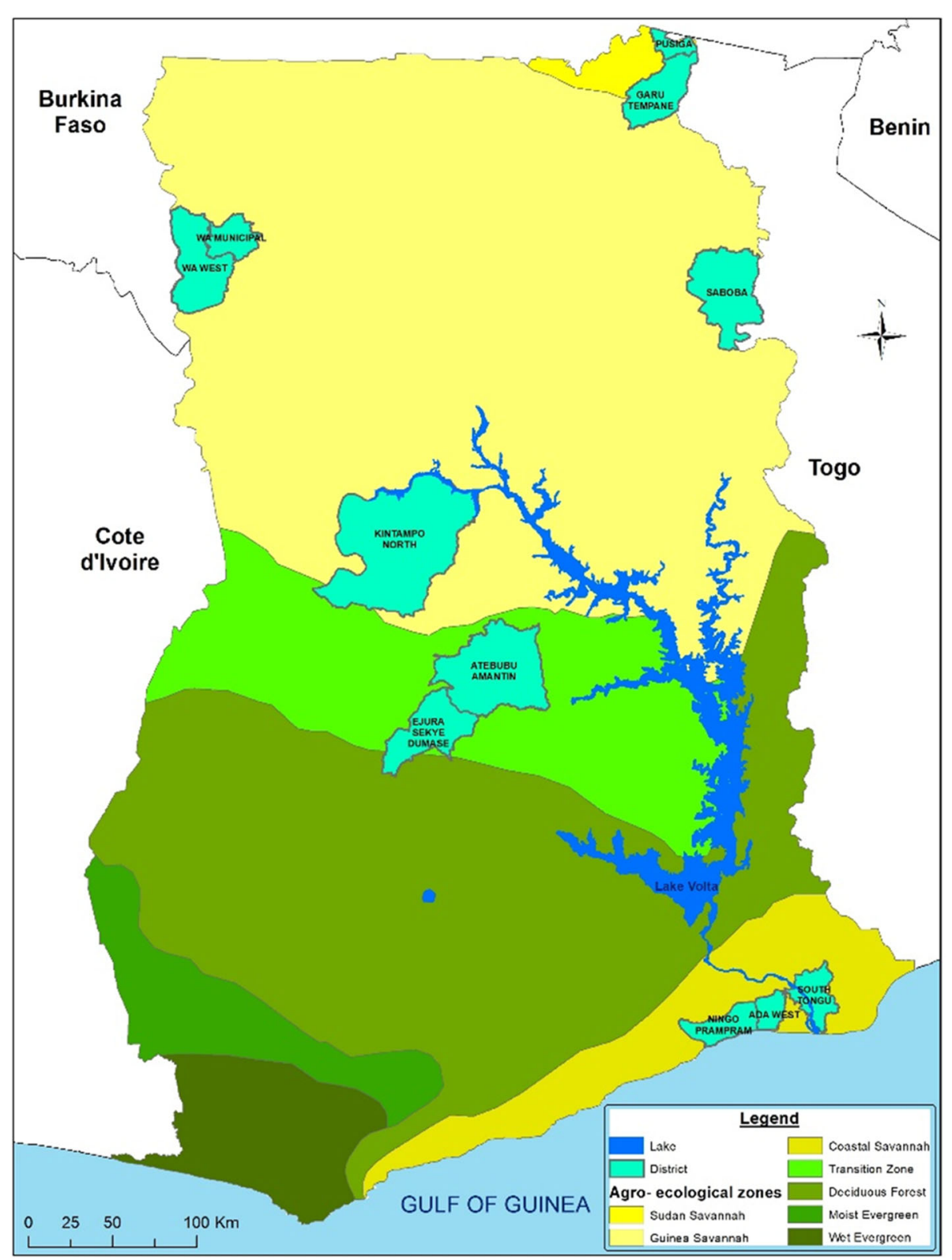

Fig. 1 Agro-ecological zones in Ghana and study districts. Districts (turquoise blue areas) were selected from the Sudan savannah (yellow area in the north-east corner), Guinea savannah (canary yellow area in the north), the forest to savannah Transitional zone (lime green area in the middle), and Coastal savannah (lemon yellow area in the south). Two to three districts were selected from each of the four agro-ecological zones noted for cattle production. Ghana is surrounded by Cote d'Ivoire to the west, Togo to the east, Burkina Faso to the north, and the sea Gulf of Guinea (Maya blue area) to the south 
Ashanti and Eastern Regions. The proportions of total cattle population in the agro-ecological zones are $74 \%$ in the Guinea and Sudan savannahs, 5\% in the Coastal savannah, $17 \%$ in the Transitional zone, and $3 \%$ in the forest zone, based on the projected 2012 cattle population (MOFA 2016). Herd sizes (in kraals) are smaller in the northern (Guinea and Sudan) savannah (10-50 heads) than in the southern (Coastal) savannah (50-200 heads) (Otchere and Okantah 2001). This observation agrees somewhat with our survey data which showed that the largest herds were in the Coastal savannah (14600) compared to Guinea savannah (12-288) and Sudan (8-123). Generally, cattle population density is highest in the Sudan savannah zone followed by the Coastal savannah, Guinea savannah, and the Transitional zone, in that order. Cattle numbers are low in the humid zone of Ghana (evergreen forest and deciduous forest) due to the incidence of trypanosomiasis, which adversely affects cattle production. Animal healthcare facilities are available in large towns and cities, and smallholders mostly depend on public animal healthcare workers and veterinarians. All the cattle production zones in Ghana fall under the sub-humid agro-climatic zone. By contrast, the major cattle production areas in West Africa fall within the semi-arid climatic zone.

The agro-ecological zones have varying rainfall distribution and landscape. The mean annual rainfall (800-1300 $\mathrm{mm}$ ) and the number of rainy days in these zones support crop production. Rainfall distribution is bimodal in the Transitional zone and Coastal savannah, leading to a major and minor season for crop farming, respectively. However, it is unimodal in the Guinea savannah and the Sudan savannah with a single cropping season. The Coastal savannah is characterised by low plains, particularly, the Accra Plains. The Guinea and Sudan savannahs also have extensive flatlands. The Transitional zone has a combination of forest and savannah. The southern part of this zone has a topography that is fairly rolling with valleys and peaks, while its northern portions consist of undulating and flatland. In all of the four agro-ecological zones, livestock depends on natural pastures and rangelands within unimproved pastures, savannah woodland, and bush fallows. The availability and quality of pastures vary with rainfall; pastures are abundant in the wet season but scarce in the dry season (MOFA 2016).

Cattle production in Ghana occurs mostly in arable areas under pastoral systems. Though crop production is the main form of land use in all the agro-ecological zones in the country, pure grazing systems can be found in the savannah and transitional zones. The production system is mainly extensive, relying on natural pasture and little external input. Crop production abounds in the cattle production areas, and cattle do not travel very far to look for grass; thus, they have to be restrained in enclosures called kraals at night and when they are not feeding so that they do not destroy crops. The kraals also offer some form of security from theft. According to Otchere and Okantah (2001), the West African shorthorn (WASH) is the most populous breed, constituting over $60 \%$ of the cattle population. Over the years, the WASH has been crossed with zebu cattle, especially the White Fulani, to form a cross called Sanga. The Sanga are bigger than the WASH and used for both beef and milk production. Additionally, there are some intensive systems of production that use crosses from local cattle and exotic breeds like the Friesian, and pure breeds like the Jersey; the major output is milk. Since the crosses and pure breeds are not well adapted to the climate, they are not taken out to graze like the local breeds. Instead, forage is cut and brought to them. However, cattle numbers in these intensive production units are negligible compared with the numbers involved in the extensive production system. According to MOFA (2016), the few intensive systems available are found on farms of parastatals and among some 100 households who keep Friesian-Sanga crossbreds or Jersey cows in their backyard, all situated in the peri-urban areas of southern Ghana. The Transitional zone is increasingly becoming a major livestockproducing zone, because feed and water are plenty. Also, due to tree clearing, the tsetse fly population is significantly decreasing (Oppong-Anane et al. 2008).

Cattle markets exist in some large towns and cities. Individuals may go to the farm gate/kraal to purchase animals for their own use. An itinerant trader may also go round several kraals, purchasing cattle, assembling and transporting them to the towns and cities, or sending them to village markets where they are retailed or sold to other traders who may transport them to markets in urban and coastal towns (MOFA 2016). Also, milk is produced, and part of it is consumed by farm families at home or sold as fresh milk in peri-urban markets for direct consumption or further processing into local cheese and yoghurt (Omore et al. 2004).

Three main players can be identified in cattle production in Ghana: a kraal owner, a cattle owner, and a herdsman. Following Hill (1970), we provide profiles of these players. The kraal owners and cattle owners we studied are mostly natives. However, herdsmen are a combination of natives and foreigners, including Fulani. Nevertheless, Fulani in the country are often descendants of immigrants who are living in the country almost permanently. A kraal owner is a person who owns cattle and has space and or housing to keep cattle. A kraal is called zag and a kraal owner zagsop among the Dagare in the Guinea savannah and natsu and natsutse among the Dangme in the Coastal savannah. The kraal owner may have built the kraal or inherited it. He is the one the herdsman considers himself responsible to. A son of 
an elderly father or household head may be viewed as the kraal owner. A kraal owner may own other kraals individually or share with a number of close relatives. Few kraal owners own all the cattle in the kraal; however, the kraal owner typically owns the service bull. A cattle owner is someone who has a few cattle but no facilities or labour for keeping them and, therefore, entrusts the animals into the care of a kraal owner. These cattle owners include businessmen and women, civil servants, relatives, and friends. A cattle owner is neither a kraal owner nor a very close relative (such as a wife, brothers, or sons) of the kraal owner who manages his animals. $\mathrm{He}$ is not a joint kraal owner and pays the kraal owner for the latter's services. The main duties offered to the kraal owner includes hiring a herdsman and managing the herd. These duties are uniform across most kraals and therefore regarded as standard.

A herdsman is someone who takes care of cattle he does not own. The herdsman's main duties include taking out the cattle to graze, providing security for them, and assisting the kraal owner in herd management. These duties are also uniform for most herdsmen and therefore regarded as standard. In grazing systems, cattle are fed on naturally growing pasture, which requires that cattle are herded. Most cattle farmers are also crop farmers who usually employ their own labour on their farms and often use family labour to herd cattle. The familial herdsman may be a young man and not receive any financial rewards. However, he is cared for by the kraal owner and is often given cattle as dowry for a bride when he is ready to marry. Alternatively, herdsmen can be hired to herd cattle (Otchere and Okantah 2001; Otchere et al. 1997). Herdsmen could be natives or foreigners particularly Fulani.

Livestock functions in developing countries including Ghana include output (meat and milk), input for crop farming (manure and draught power), asset (insurance), and socio-cultural functions (Jahnke 1982; Moyo and Swanepoel 2010). In Ghana, cattle are kept for meat and milk. Cattle manure is often used as input in crop production to improve soil fertility. Additionally, bullocks are sometimes used for ploughing or animal traction. The asset function also appears to be prominent. People in formal employment sometimes keep cattle as savings towards retirement and adverse income shocks. This is also the case for crop-livestock farmers who depend on crop sales for their regular income and view cattle as saving to be used in times of need. By contrast, in the arid agro-ecological zones of tropical Africa, where it is too dry to produce crops, milk forms a major output of the livestock production systems, and households rely on it for subsistence (Jahnke 1982). However, in the subhumid agro-ecological zone, the output function of cattle is not as important as in the arid zone, because here farmers rely more on crops for subsistence. The sociocultural function of cattle production appears important as cattle are used as dowries in marriage ceremonies among natives of the Guinea and Sudan savannahs. Cattle are also sacrificed during religious ceremonies by Muslims and practitioners of African traditional religion (Oppong-Anane et al. 2008).

The contribution of livestock to the overall agricultural output in the economy is small, only 1.3\% in 2014 (GSS 2015), but important. According to GSS (2014), over four million households in Ghana own livestock. Their livestock provides valuable nutrients like protein for households and manure and draught animal power for crop production. Moreover, having livestock reduces income risks associated with crop failure and facilitates the accumulation of wealth to finance both planned and unplanned expenditure (Moyo and Swanepoel 2010).

\section{Agricultural contract types and drivers}

In this section, we discuss the various types of contracts, the drivers of these contract types, and how this can be applied to cattle production in Ghana. Also, hypotheses are formulated regarding the drivers of contract type in cattle production.

A contract can be viewed as an agreement between parties regarding their respective duties and rewards for performing the duties. We envisage a two-person contract between a principal (or employer) and an executing agent (or employee). These contracts can be characterised in several ways. First of all, they may be classified based on whether the contract terms are explicitly specified or not. Explicit contracts are those in which the contract terms are specified ex ante. Implicit contracts do not specify contract terms ex ante. They are typically long-term arrangements between parties based on production outcomes (Baker et al. 1997; Baker et al. 2002). Furthermore, Baker et al. (2002) explain that implicit contracts could include unwritten understandings between bosses and subordinates about task assignment, promotion, and termination decisions.

Explicit contracts can be further classified by looking at the remuneration of the employee. As noted earlier, the employee's duties (i.e. those of the kraal owner or the herdsman) are regarded as standard. We distinguish between three contract types: first, a fixed-rent contract, where the employee takes all the output and bears all the input cost and, in return, transfers a fixed payment to the employer; second, a fixed-wage contract, where the employer takes all the output and bears all the input cost and, in return, pays the employee a fixed wage; and third, a share contract, where both parties share the output and maybe also input costs (Braverman and Stiglitz 1986; Laffont and Matoussi 1995). 
Additionally, we define a mixed variant of the fixedwage contract and the implicit contract: the employer takes all the output and bears all the input cost, but the employee's remuneration is not explicitly specified. We refer to this type as input-subsidy-only contracts. Here, the employee is explicitly assured of full payment of input costs or reimbursement of this cost if the employee pre-finances (provides cash upfront to purchase) inputs for the employer. Additionally, the employee has rights to some by-products from the farm.

The distinction between these contract types (explicit/ implicit; fixed-rent, fixed-wage, share; input-subsidyonly) will be used to classify our data on cattle contracts.

\section{Drivers of contracts}

Let us now turn to what can explain the choice for a specific contract type. In the literature, two main theories have been proposed: agency theory and transaction cost theory.

Agency theory considers a contract where the employee typically has information that the employer does not have. For instance, the employer may not know how hard the employee will work. Yet the employee's effort level cannot be contracted upon as it is not observable. This could lead to moral hazard or a hidden-action problem (Laffont and Martimort 2009; Hölmstrom 1979; Holmstrom and Milgrom 1991; Grossman and Hart 1983). Furthermore, the employee could be a low-ability or high-ability worker, resulting in an adverse-selection or hidden-information problem (Hallagan 1978; Allen 1985; Singh 2000). To resolve the hidden-action problem, the employer offers the employee a contract that gives the employee the necessary incentives to perform well. Moreover, when the employee is risk averse, a riskneutral employer could design a share contract so that the latter's remuneration is tied to his effort. Also, the share contract insures the risk-averse agent against output risks, making it more appealing than a fixed-wage contract or a fixed-rent contract. This explains the occurrence of share contracts.

When the employer is faced with hidden information related, for instance, to the worker's ability to perform, he could design a set of different contracts such that a low-ability worker is worse off if he accepts a contract targeted at a high-ability worker, and vice versa. In this way, workers would reveal their true type. This option can explain the coexistence of fixed-wage, share, and fixed-rent contracts, where the lowest-ability workers accept fixed-wage contracts and the highest-ability workers accept fixed-rent contracts.

Thus, agency theory predicts that when an employee is risk averse and prone to moral hazard, it is optimal for the employer to offer a share contract. Also, when employees have private information about their abilities, the employer designs different contracts for different ability levels and employees select the contract type best suited to their ability.

Transaction cost theory focuses on the transactions among parties (Kim and Mahoney 2005). There is no distinction between principals and agents, and they are assumed to be risk neutral. Transactions are exchanges of goods and services between transacting parties. Costs are incurred during transactions, and these include search cost, bargaining costs, and enforcement cost (Dahlman 1979). For instance, a party that wants a good to buy must search for the good, measure the value of the good and bargain, and be sure that goods of the right value are delivered to him by the seller. If the right goods are not delivered, this is redressed through appropriate channels.

Also, transaction costs arise from man's bounded rationality and self-seeking behaviour. Because cognitive competence is limited, all contingencies relevant for good performance cannot be taken care of or be specified ex ante in a contract. Thus, contracts become incomplete, and this combined with man's self-seeking behaviour means that governance structures have to be put in place to take care that both parties behave cooperatively (Williamson 1989, 2000). Hence, transaction cost theory involves the analysis of the costs and benefits of alternative governance structures that can be implemented to ensure that parties maximise their mutual benefits. Because transactions differ in their attributes, the optimal governance structure typically varies. Important attributes include transaction frequency, the uncertainty to which transactions are subject, and asset specificity. Uncertainty arises from three sources: (1) changing state of nature, (2) lack of communication between contract parties, and (3) behavioural uncertainty arising from the strategic behaviour of parties when they interact. Asset specificity refers to the ease of moving assets to other transactions. The more specific an asset is, the more difficult and thus the more costly it is to use in other transactions (Williamson 1989).

As mentioned earlier, to place value on what is exchanged, it must be measured. However, some measurements are difficult, and one party may have a better knowledge of the value than the other (Barzel 1982; Williamson 1989). Measurement costs may be excessive; hence, exchange parties engage in contracts that eliminate or reduce measurement. For instance, Barzel (1982) notes that when it is less difficult to measure performance, lump-sum arrangements are preferred. When measurement difficulties increase, it could be too costly to reach an appropriate estimation of the lump-sum.

The way transactions are organised or governance structures, including contracts, affect transaction cost. Furthermore, transaction attributes affect governance 
structures and contacts. Therefore, transaction cost theory predicts that given the attributes of a particular transaction, a particular governance mechanism or contract is chosen to minimise cost and increase mutual benefits for both parties to a contract. Similarly, difficulties in measurement affect the contract forms used by parties.

\section{Application to cattle production and hypotheses}

Now, we apply the theories elaborated to cattle production and formulate hypotheses regarding drivers of variations in contract type.

Attributes of transactions vary with agro-ecological zones. For instance, environmental uncertainty which relates to variations in weather and adverse shocks differs from one agro-ecological zone to another. As noted earlier, a component of transaction costs relates to monitoring and enforcement. The need to monitor arises from behavioural uncertainty or opportunism of parties to a transaction. Such opportunism could be reduced if parties to a transaction are able to monitor the performance of tasks. The time and opportunity cost of doing this depend on outside employment opportunities or outside options the monitoring party has. These outside options vary from zone to zone and further strengthen the potential correlation between contracts and zones. Together, all of these suggest the following hypothesis.

1. Contracts in cattle production vary with agroecological ones.

We now isolate specific attributes of transactions and examine how they could impact on contracts.

Uncertainty includes environmental uncertainty which relates to a number of rainfall months in different zones which influence output risk and measures put in place by parties to reduce the risk on either party. Implicit contracts which have inherent insurance elements could prevail in environments with high output risk. Consequently, we expect that environmental uncertainty will be correlated with contracts. Accordingly, we arrive at a hypothesis relating implicit contracts to environmental risk.

\section{Implicit contracts are more prominent in zones} with higher environmental risk.

Transacting parties whose outside options, and hence opportunity cost of monitoring, are higher are less likely to engage in transactions that require monitoring. Fixedwage contracts and subsidy-only contracts in which an employer supplies all purchased inputs require monitoring to ensure that employees use them efficiently. Thus, in zones where outside options for employers are higher, subsidy-only contracts and fixed-wage contracts will be engaged in less. Put differently, provision of inputs by employers will be low in zones in which their monitoring cost is high. Similarly, for employers engaged in share contracts and contributing to input provision, the share of inputs supplied by the employer (employee) will be lower (higher) in zones with higher outside opportunities for the employer. The following hypotheses arise from the foregoing.

3. Receipts of input subsidy by kraal owners are associated more with areas of low outside options (opportunity cost of monitoring) for the cattle owner.

4. Share of calves received by kraal owner increases as outside options for cattle owner increases.

Transaction frequency could relate to contract duration. Longer contract durations allow repeated interaction between parties which allows for punishment of parties that renege on contracts and that makes self-enforcement of contracts possible. Thus, most cattle production contracts are likely to have a long or indefinite duration. Nevertheless, these indefinite contracts could be terminated by either party to a contract. For instance, a herdsman's contract could be terminated if he steals or incurs unexplained losses of animals. The herdsman could also walk out of a contract if the thinks he is not being rewarded enough for his toils. The following hypothesis is thus obtained.

5. Contracts in cattle production are more likely to have indefinite or long-term contract durations.

When there is likelihood of opportunistic behaviour in the mist of measurement problems, contracts that reduce opportunistic behaviour will be adopted. Measurement problems or cost could be associated with both sharing of production inputs, including veterinary inputs, labour cost, and measurement and sharing of output such as milk. Noting that it is difficult or costly to measure the quantity of milk harvested by a herdsman, under extensive production systems, the herdsman could be allowed to take a high share of milk harvested so that he is motivated, as predicted by agency theory, to take good care of cows to produce enough milk for consumption by both humans and calves. Also, opportunism which is prevalent in many relationships can be reduced depending on whether one is dealing with a family member or not. Thus, where the danger of opportunistic behaviour is ameliorated by kinship, fixed payment is offered to the herdsman without the fear of milk output being underreported or stolen.

6. Familial herdsmen are more likely to receive nonmilk fixed payments. 
Herdsmen are often thought to have different abilities in herding. Thus, the kraal owner could design contracts to suit each ability type and allow the former to select contracts that are most appropriate for them. However, in a community where people are known to one another, information about herdsmen's ability is most probably not hidden.

\section{Methodology}

In this section, we present details of the sampling and data collection procedures that were used. Furthermore, we present procedures used to analyse the data.

\section{Sampling procedures}

A multi-stage stratified random sampling procedure was used to select kraal owners, cattle owners, and herdsmen. Districts were selected, and a list of kraal owners in the districts was made.

We selected two or three districts from each of the four agro-ecological zones known for cattle production, namely the Guinea savannah, Sudan savannah, Transitional zone, and Coastal savannah (Appendix Table 7). Three districts were chosen from the Guinea savannah, as it is the biggest zone known for cattle production. Three districts were also picked from the Transitional zone, because this zone is becoming increasingly important for cattle production. In the Coastal savannah, we selected three districts. However, two districts were chosen from the Sudan savanna, which is the smallest savannah zone in Ghana. These districts are assumed to be representative of the various agro-ecological zones in terms of rainfall characteristics and cattle production systems, because they have similar features as the zones to which they belong, as described in the "The study area" section. Different agro-ecological zones and districts were selected so that a comprehensive view of cattle production across the country will be obtained. Besides, it was thought that the different agro-ecological zones could have different features with different implications for contract types in cattle production.

In all districts, lists of known kraal owners were prepared with the assistance of local veterinary technicians and agricultural extension agents. The number of kraal owners identified and listed in each district was between 60 and 130. The kraal owners were identified largely from records of mass vaccinations. Kraal owners were also identified through the familiarity of the veterinary technicians and agricultural extension officers with them. Using the lists, we randomly selected $40 \mathrm{kraal}$ owners from each district for personal interviews. However, not all kraal owners were available to be interviewed. Therefore, data was collected from a total of 342 kraal owners across the country. A herdsman who worked for a selected kraal owner and one cattle owner who had entrusted his cattle into the care of this kraal owner were also selected for face-to-face interviews.

Consequently, from each kraal, three respondents were interviewed: the kraal owner, a herdsman, and a cattle owner. In the case of more than one herdsman, the most senior one was interviewed since he was deemed to be the most knowledgeable. If there was more than one cattle owner, the first one who was available was interviewed. Nonetheless, there were some kraals where it was difficult to get the herdsmen and cattle owners for interviews. A total of 260 cattle owners and 284 herdsmen were interviewed across all the agro-ecological zones. Since we were interested in studying management arrangements between contracting parties, we did not include kraal owners who herded their own cattle in the sample frame, because they did not have a counterpart herdsman. Also, we tried interviewing all three parties connected to a kraal. Hence, we made sure, as much as possible, that kraals were included in the sampling frame that had all three parties, or at least two. Often, there are multiple owners of cattle in a particular herd (Okantah et al. 1999; Otchere and Okantah 2001; Hill 1970). Thus, it is quite easy to get at least two parties in a kraal. Despite the exclusion of kraal owners who herded their own cattle, our sample is still representative of the majority of kraals or kraal owners in the population, because typically, most kraal owners do not herd their own cattle.

\section{Data collection and procedure}

Data was collected using structured questionnaires. Prior to the questionnaire preparation, four experts (a past Director of Animal Production Department of the Ministry of Food and Agriculture (MoFA) in Ghana; a Regional Livestock Officer of MoFA; a Livestock Officer of the Animal Research Institute (ARI), Ghana; and a former herdsman also of ARI were interviewed for a general description of prevailing contracts. Based on their reports, questionnaires were prepared. We then trained enumerators in two districts (Atebubu-Amantin and Ejura-Sekyedumase) and pretested the questionnaires there. Based on the responses during pretesting, the questionnaires were revised. Next, a team of enumerators in each district were trained again, and then the questionnaires were administered from January 2014 to March 2014. The enumerators were mostly agricultural officers and veterinary technicians who were familiar with the respondents. This ensured that respondents were comfortable to answer questions and inaccurate answers could be easily detected by the enumerators. Questionnaires were administrated in Ada West in July 2015 due to logistical constraints. Informed consent was obtained from all individual participants in the study.

Data of the three sets of respondents (kraal owners, cattle owners, and herdsmen) were entered into Microsoft 
Excel spreadsheets and exported to IBM SPSS Statistics version 20 for further processing and analysis. We analysed contract characteristics based on kraal owners' responses. Responses from relevant herdsmen and cattle owners were used to cross-check kraal owners' responses. In the case of inconsistencies, we used responses from the respondent category that we deemed better informed to answer the particular question. For instance, though both herdsmen and kraal owners were asked to comment on production indicators, we assumed that the herdsmen were better informed of these indicators. Herdsmen are with the animals on a daily basis, know the animals individually, and have first-hand evidence of their performance. In situations where data was missing for the kraal owner, especially regarding contract parameters, responses from the relevant cattle owner and herdsman provided the data to fill the gap. We used descriptive statistics, including frequencies and percentages, to summarise the information. Also, we crosstabulated some variables to assess the association between them. The significance of these associations was tested using the chi-square test since we dealt with categorical variables. The strength of the association was tested using Cramer's $V$ statistics because the alternative measure, contingency coefficient, has a weakness of its maximum being dependent on the dimensions of the contingency table. Questionnaires completed during pretesting were not included in the final sample.

\section{Results}

We set out to answer two main questions: Firstly, what are the types of contracts in cattle production in Ghana? Secondly, how can we explain the variations in contract types in cattle production using contract theory? Two sets of contracts, namely between kraal owner and herdsman and between kraal owner and cattle owner, were identified. The results for contract types and their drivers, under each of the two categories, are presented.

\section{Characteristics of cattle owner-kraal owner contracts}

The cattle owner-kraal owner contracts were of two kinds (explicit or implicit) depending on whether the terms of the contract were explicitly agreed on. Approximately $60 \%$ of the sampled cattle owner-kraal owner contracts were explicit contracts; the kraal owner's duties and remunerations were explicitly specified. These duties were generally standard and were mainly two. First, he searches for a herdsman to graze the cattle. Second, he makes herd management decisions. However, they have varying responsibilities for providing material inputs including veterinary drugs and care, and inputs for herdsmen's upkeep. The kraal owner could be responsible for the total cost of material inputs for the cattle owner's animals, share material inputs cost with the cattle owner, or the cattle owner bears all the cost for material inputs. The kraal owner often pre-finances (or advances cash for purchasing) material inputs required from the cattle owner. Thus, the kraal owner receives reimbursement of this cost which we term input subsidy since it reduces the overall cost borne by him. These variations are accounted for in a cattle owner's rewards to a kraal owner.

The kraal owner's remuneration in the explicit cattle owner-kraal owner contracts had three components. The first was the share of the cattle owner's animals (calves). Calf sharing could go this way: when a cattle owner's cow produces an offspring the first time, the offspring (calf) belongs to him. However, when that same cow calves a second time, the calf is given to the kraal owner. The second component was the periodic (usually monthly) fixed payment. The fixed payment was often cash. The third was input subsidy given to the kraal owner as payment for the cattle owner's share of material inputs. The payment of input subsidy, irrespective of what it is used for, is primarily in fulfilment of the cattle owner's obligation to the kraal owner. The subsidies were in cash or kind. In-kind contribution towards kraal owner's expenses for herdsman's upkeep included food provisions. Alternatively, the kraal owner could be supported to assist the herdsman to cultivate a piece of land for himself. Such assistance could include ploughing land for him free of charge.

Implicit contracts had the remuneration to the kraal owner not explicitly specified at the inception of the arrangement although the kraal owner's basic duty of making management decisions was understood.

\section{Drivers of cattle owner-kraal owner contracts}

Various cattle owner-kraal owner contract types were observed, and parties to the contract chose one type or another. Factors that shaped these contracts were explored. Based mainly on the transaction cost theory, hypotheses were derived regarding the association between the contract type and drivers of contracts.

Firstly, we tested the hypothesis that contracts generally varied with agro-ecological zones. The cattle ownerkraal owner contracts showed a different mix of compensations, and their frequencies varied across zones (Table 1). These contracts-fixed payment in cash with or without subsidies, share contracts with or without subsidies, input-subsidy-only, and implicit contractswere significantly associated with the zones $\left(\chi^{2}(9)=\right.$ 284.25, $p=0.01$ ) supporting the hypothesis. This association was relatively strong (Cramer's $V=0.54$ ). Whereas fixed payment in cash (with or without input subsidy) was not observed in the Coastal savannah and only a few times in the Guinea savannah, and Sudan savannah, it was quite prominent in the Transitional zone. Share contracts, with or without input subsidy, occurred the 
Table 1 Distribution (percentage) of cattle owner-kraal owner contract types by agro-ecological zone

\begin{tabular}{|c|c|c|c|c|c|}
\hline \multirow[t]{2}{*}{ Contract type } & \multicolumn{5}{|c|}{ Agro-ecological zone } \\
\hline & Coastal & Guinea & Sudan & Transitional & Total \\
\hline Fixed payment in cash & 0 & 8.1 & 5.4 & 11.9 & 6.2 \\
\hline Fixed payment in cash plus input subsidy & 0 & 0 & 1.4 & 18.6 & 3.7 \\
\hline Share contract & 65.4 & 1.8 & 0.0 & 11.9 & 18.6 \\
\hline Share contract plus input subsidy & 28.2 & 0.9 & 1.4 & 6.8 & 5.2 \\
\hline Input subsidy & 0 & 30.6 & 13.5 & 25.4 & 18.3 \\
\hline Implicit contracts & 6.4 & 58.6 & 78.4 & 25.4 & 44.4 \\
\hline Total percentage & 100 & 100 & 100 & 100 & 100 \\
\hline Total number of kraals & 78 & 111 & 74 & 59 & 322 \\
\hline
\end{tabular}

Source: field data

most in the Coastal savannah, followed by the Transitional zone; they were virtually absent in the Guinea and Sudan savannahs. Contracts with only input subsidy were mostly found in the Guinea savannah, followed by the Transitional zone and the Sudan savannah; these contracts were negligible in the Coastal savannah.

Implicit contracts were quite high in the sample (Table 1). In the Guinea savannah and the Sudan savannah, implicit contracts even formed the majority of contracts. Implicit contracts occurred the least in the Coastal savannah, while a quarter of contract types in the Transitional zone also had this feature. We tested the second hypothesis that implicit contracts occurred more in zones with higher environmental uncertainty. The Guinea savannah and the Sudan savannah had longer periods of dryness ( 7 months) and only one rainfall season compared to 5 months of dryness and two rainy seasons in the Transitional zone and Coastal savannah. The association of implicit contracts with the Guinea and Sudan savannahs is significant $\left(\chi^{2}(3)=97.8, p=\right.$ 0.01 ) and relatively strong (Cramer's $V=0.55, p=0.01$ ). The distribution of all explicit contracts combined and implicit contracts are shown in Table 2.

The third hypothesis we tested was that more input subsidies occurred (or were received by kraal owners) in zones where cattle owner's cost of monitoring was lower because of lower cattle owners' outside options. The cost of monitoring in the Guinea and Sudan savannahs are lower than that in the Transitional zone and the Coastal savannah. The proportion of cattle owners who subsidised kraal owner expenses on the care of herdsmen was low in the Coastal savannah (5\%). This was a little higher in the Guinea savannah (46\%), the Sudan savannah (67\%), and the Transitional zone (15\%). The association between agro-ecological zones and kraal owner's receipt of subsidy for the care of herdsmen was significant $\left(\chi^{2}\right.$ (3) $=29.12, p=0.01$ ) and relatively strong (Cramer's $V=$ $0.47, p=0.01)$. This supports the observation that inputsubsidy-only contracts are more in zones with a lower outside option for cattle owners and therefore lower monitoring cost.

The most important component of input subsidy was a contribution towards veterinary care of cattle. This was highest in the Transitional zone (56\%), followed by the Guinea savannah zone (33\%) and Coastal savannah zone (29\%). It was lowest in the Sudan savannah (9\%). The association between agro-ecological zone and kraal owner receipt of subsidy for veterinary care was significant $\left(\chi^{2}(3)=30.36, p=0.01\right)$, and the association was moderately strong (Cramer's $V=0.32, p=0.01$ ). However, cattle owners in the zones with lower monitoring costs (Guinea and Sudan) had lower percentages of kraal owners receiving input subsidy which is contrary to the hypothesis.

Hypothesis 4 says that the kraal owner's share of calves increases as cattle owner's outside options or cost of monitoring goes up. For the two zones where calf sharing between the kraal owner and cattle owner was reported, we expected that the cost of monitoring would be higher in the Coastal savannah than in the Transitional zone. The share of calves received by kraal owners was associated with whether the zone was Coastal or Transitional (Fisher's exact test, $p=0.01$ ). This association was relatively strong (Cramer's $V=0.46, p=0.01$ ) supporting the hypothesis. Table 3 reports on the sharing proportions under share contracts. First of all, almost half of the explicit contracts involved the sharing

Table 2 Distribution (percentage) of explicit and implicit cattle owner-kraal owner contracts by agro-ecological zones

\begin{tabular}{llllll}
\hline Contract type & \multicolumn{4}{l}{ Agro-ecological zone } & Total \\
\cline { 2 - 5 } & Coastal & Guinea & Sudan & Transitional & \\
\hline Implicit contract & 6.4 & 58.6 & 78.4 & 25.4 & 44.4 \\
Explicit contract & 93.6 & 41.4 & 21.6 & 74.6 & 55.6 \\
Total percentage & 100.0 & 100.0 & 100.0 & 100.0 & 100.0 \\
Total number of kraals & 78 & 111 & 74 & 59 & 322 \\
\hline
\end{tabular}

Source: field data 
of calves. Kraal owners got either one out of every three calves or one out of every two calves. The majority of kraal owners under share contracts in the Coastal savannah had one out of two animals. The frequency of share contracts was negligible in the Guinea and Sudan savannahs, since not more than two cases of share contracts were observed in each zone. Giving one out of every three calves to the kraal owner occurred more in the Transitional zone than in the Coastal savannah.

Also, we tested the hypothesis that cattle owner-kraal owner contracts have mostly long duration. A chi-square test showed that significantly more cattle owner-kraal owner contracts had indefinite duration rather than definite duration $\left(\chi^{2}(1)=117, p=0.01\right)$.

In brief, we found some dichotomy in cattle ownerkraal owner contracts: Some contract types were explicit while others were implicit. The contract types were associated with agro-ecological zones. Additionally, most contract types had a long or indefinite duration.

\section{Characteristics of kraal owner-herdsman contracts}

Among kraal owner-herdsman contracts, we found contracts, both explicit and implicit. In the explicit contracts, the remuneration given by the kraal owner to the herdsman was specified or explicitly agreed on. In the implicit contracts, the remuneration to the herdsman was not specified explicitly making them implicit contracts. In this case, the herdsman's rewards appeared to be tacit.

Explicit contracts formed the vast majority of the kraal owner-herdsman contract. Herdsmen's specified rewards were of two kinds: (1) offering the milk harvest and (2) a fixed payment, which was in cash or in kind (other than milk). Fixed payments of cash were usually monthly payments. Fixed payments in kind were of two types: regular periodic payments in kind, especially food and animals, and the award of a breeding animal to the herdsman after the expiration of his contract. It is not unusual for kraal owners to make periodic deliveries of bags of rice or quantities of other cereal meals to herdsmen. Giving the entire milk output could be the only reward, or it could be supplemented by a fixed payment in cash or kind. The kraal owner and herdsman were asked whether the terms of their agreement were negotiated

Table 3 Distribution (percentage) of kraal owner's share of calves by agro-ecological zone

\begin{tabular}{llll}
\hline $\begin{array}{l}\text { Share of calves } \\
\text { received by kraal } \\
\text { owner }\end{array}$ & \multicolumn{2}{l}{ Agro-ecological zone } & Total \\
\cline { 2 - 3 } & Coastal & Transitional & \\
\hline One half & 72.9 & 9.1 & 64.2 \\
One third & 27.1 & 90.9 & 35.8 \\
Total percentage & 100.0 & 100.0 & 100.0 \\
Total number of kraals & 70 & 11 & 81 \\
\hline
\end{tabular}

Source: field data between them. Herdsmen also had the chance to say something about the offer that was given to them. The negotiations focused on whether a herdsman would be entitled to all milk harvested and whether any fixed payment would be in cash and how much.

Implicit contracts were in the minority in the sample (3\%). We also characterised kraal owner-herdsman contracts with respect to the duration of the agreements. One set of contracts, which were usually short term, had the duration given, while the second set of contracts had an indefinite contract period. Also, contract duration could be part of the negotiation. Contract terms were negotiated in the Coastal savannah in over half of the cases (60\%). However, negotiations occurred less in the rest of the agro-ecological zones (30-44\%).

\section{Drivers of kraal owner-herdsman contracts}

The association of kraal owner-herdsman contractsmilk with or without fixed payments, fixed payment only in kind or cash, and implicit contracts-with agroecological zones was significant $\left(\chi^{2}(6)=131.26, p=0.01\right)$ and was relatively strong (Cramer's $V=0.44$ ) in conformity with the hypothesis that contracts were related to zones. Herdsmen received the entire milk output in the majority of the contracts in the Coastal savannah, Transitional zone, and Guinea savannah; it occurred in less than half of the contracts in the Sudan savannah (Table 4). Offering the milk output was almost always combined with fixed payments in cash or kind. Payment with only milk output occurred to a very small extent in the Coastal savannah. However, kraal owner-herdsman contracts with only fixed payment, both in cash or kind, were observed in slightly high percentages only in the Coastal savannah and the Sudan savannah. It hardly occurred in the Guinea savannah and the Transitional zone.

Fixed payment contracts whether in cash or kind occurred in all zones. The proportion of implicit contracts varied across zones but was pretty low. Although the occurrence of this contract type was low, it occurred the most in the Sudan savannah, followed by the Coastal savannah. It was virtually non-existent in the Guinea and Transitional zones.

The hypothesis that a herdsman's remuneration depended on whether he was family of the kraal owner or hired was tested. The association of herdsman type with herdsman's remuneration-milk with or without fixed payment, fixed payment only in cash or kind, and implicit contracts-was significant $\left(\chi^{2}(2)=84.31, p=\right.$ 0.01 ). The relationship was relatively strong (Cramer's $V=0.50$ ). Herdsmen who were family members mostly received fixed payments in cash or in kind, whereas hired herdsmen often received in addition to some fixed payment also milk output (Table 5). The combination of fixed payments and milk output among family herdsmen 
Table 4 Distribution (percentage) of kraal owner-herdsman contract types by agro-ecological zone

\begin{tabular}{|c|c|c|c|c|c|}
\hline \multirow[t]{2}{*}{ Contract type } & \multicolumn{4}{|c|}{ Agro-ecological zone } & \multirow[t]{2}{*}{ Tota } \\
\hline & Coastal & Guinea & Sudan & Transitional & \\
\hline Milk output & 1.2 & 0.0 & 0.0 & 0.0 & 0.3 \\
\hline Milk output plus fixed payment in cash & 1.2 & 10.8 & 0.0 & 6.3 & 5.3 \\
\hline Milk output plus fixed payment in kind & 37.5 & 37.5 & 26.0 & 14.3 & 30.6 \\
\hline Milk output plus fixed payment in cash and kind & 25.0 & 50.0 & 7.8 & 77.8 & 39.7 \\
\hline Fixed payment in cash & 0 & 0 & 1.3 & 0 & 0.3 \\
\hline Fixed payment in kind & 28.7 & 0.8 & 55.8 & 1.6 & 20.0 \\
\hline Fixed payment in cash and kind & 3.8 & 0.0 & 1.3 & 0 & 1.2 \\
\hline Implicit contract & 2.5 & 0.8 & 7.8 & 0 & 2.6 \\
\hline Total percentage & 100 & 100 & 100 & 100 & 100 \\
\hline Number of kraals & 80 & 120 & 77 & 63 & 340 \\
\hline
\end{tabular}

Source: field data

accounted for about a third of kraal owner-herdsman contracts. Often, they took only enough milk for their household use.

Also, in the spirit of testing the relationship of contracts with zones, the hypothesis that the duration of the kraal owner-herdsman contract was fixed (definite) or not fixed (indefinite) was associated with agro-ecological zones $\left(\chi^{2}(3)=61, p=0.01\right)$. The association was relatively strong (Cramer's $V=0.54, p=0.01$ ). Whereas duration was fixed in most contracts in the Coastal savannah and the Transitional zone, this was not so in the Guinea savannah and Sudan savannah (Table 6). In these cases where the duration was not fixed, the contract duration was both unspecified and indefinite-a herdsman could work in a specific kraal for decades. It could continue until one party decides to terminate it for one reason or another. When fixed duration contracts were further put into subgroups, the duration for kraal owner-herdsman contracts which occurred most frequently in the sample when this was fixed was 3-4 years (Table 6). However, the mean duration of fixed duration kraal owner-herdsman contracts was higher in the Coastal savannah (3.6 years) than in the Transitional zone (1.7 years). The proportion of herdsmen whose contract durations were fixed was very low in the Guinea and Sudan savannahs. Yet, the mean fixed durations in the two zones were relatively high, 5.3 and 2.6 years, respectively.

In sum, kraal owner-herdsman contracts could also be divided into explicit and implicit contracts. However, implicit contracts were not prominent here. The contact types under explicit kraal owner-herdsman contracts were associated with agro-ecological zones and kinship. Contract duration could be fixed or indefinite.

\section{Discussion}

Contract variations have implications for incentives they provide for investment and productivity. Identification of factors that shape these contracts or influence their choice could provide information for promoting the choice of productivity-enhancing contract types. The findings regarding contract characteristics and factors that drive them are discussed in this section.

\section{Characteristics of cattle owner-kraal owner contracts}

The cattle owner-kraal owner contract is similar to the livestock owner-herd manager contract discussed by Turner and Hiernaux (2008) and Turner (1999), where a livestock owner entrusted his animals into the care of a herd manager. The latter provides services similar to the kraal owner, such as ensuring that animals are grazed, treated for illnesses, and managed for optimum

Table 5 Distribution (percentage) kraal owner-herdsman contract by labour type

\begin{tabular}{llll}
\hline Contract type & \multicolumn{2}{l}{ Type of labour used for herding } & \\
\cline { 2 - 4 } & Family labour & Hired labour & Total \\
\hline Milk output with or without fixed payments & 33.8 & 86.2 & 75.7 \\
Fixed payment in kind and cash & 55.9 & 13.0 & 21.7 \\
Implicit & 10.3 & 0.7 & 100 \\
Total percentage & 100 & 2.7 \\
Number of kraals & 68 & 338 \\
\hline
\end{tabular}

Source: field data 
Table 6 Distribution (percentage) of the duration of kraal owner-herdsman contracts by agro-ecological zone

\begin{tabular}{cccccc}
\hline \multicolumn{5}{c}{ Agro-ecological zone } & Total \\
\cline { 2 - 5 } & Coastal & Guinea & Sudan & Transitional & \\
\cline { 1 - 4 } Duration of agreement (years) & 3.0 & 0 & 7.7 & 42.4 & 9.0 \\
$1-2$ & 56.7 & 1.4 & 15.4 & 12.1 & 23.2 \\
$3-4$ & 3.0 & 2.8 & 0 & 0 & 1.9 \\
$5-7$ & 37.5 & 95.8 & 79.5 & 45.5 & 65.9 \\
Indefinite & 100 & 100 & 100 & 100 & 100 \\
Total percentage & 67 & 72 & 39 & 33 & 211 \\
Number of kraals & 67 & & & & \\
\hline
\end{tabular}

Source: field data

reproductive performance. According to Turner and Hiernaux (2008), the herd manager could be paid a wage or receive entrustments of animals. The wage corresponds to the fixed payments we found. The entrustments conferred entitlement to milk, which the herd manager or kraal owner could in turn pass on to his herdsmen, wholly or partially. Moritz et al. (2011) mentioned that kraal owners obtained other forms of compensation in addition to their right to milk, but it is not clear what the role of calf sharing was with regard to this.

Calf sharing contracts and sharecropping contracts are similar, since the output is shared between the principal and agent in both cases. Yet, they have some differences too. For instance, whereas in sharecropping, the tenant and landlord share output from the same season, in calf sharing arrangements, the cattle owner and the kraal owner receive their share of output in different seasons. There is simultaneous receipt of output by both parties in sharecropping, while there is sequential receipt of outputs in calf sharing contracts. When output shares are received simultaneously by the parties, output risk is even for each party. However, when parties receive their shares of output in different seasons (sequentially), the level of output risk could differ.

Fixed-rent contracts, where the kraal owner rents cattle and pays the cattle owner cash, were not found. Two reasons could account for this. We have argued that one main function of keeping cattle is to accumulate wealth to serve as an insurance substitute (Binswanger and McIntire 1987). The cattle owner whose main goal is to grow his herd is less likely to rent his cattle to a kraal owner for cash. Additionally, it is possible that animals rented out will be abused and lost.

\section{Drivers of cattle owner-kraal owner contracts}

The association of contracts with zones implied that specific features of the zones shaped the contract forms. Potential features of zones that affected contracts could be related to various elements of transaction cost. Chief among these are environmental uncertainty which has implication for output, and monitoring costs which affect monitoring of relevant parties in the contracts. Some zones have higher environmental uncertainty than others. The Guinea and Sudan savannahs have one rainfall peak and longer periods of dry season. However, the Transitional zone and the Coastal savannah have double rainfall peaks and shorter dry season and therefore less environmental uncertainty. Implicit contracts which are predominant in the Guinea and Sudan savannahs could be a response to inherent environmental risk associated with the zones. In implicit contracts, the kraal owner takes major decisions including cattle breeding and management of herdsmen. What the kraal owner receives as remuneration is not specified explicitly, but the cattle owner rewards him with cattle periodically. In transaction cost theory terms, the transaction involved here is the mutual sharing of risk, which allows cattle owner and kraal owner to deal with environmental uncertainties. Sharing of calves between cattle owner and kraal owner is the typical way of remunerating the kraal owner in locations like the Coastal savannah where environmental uncertainty is lower. Since individual herds of cattle owners are small, there is a time lag between the period one party receives his share and when the other party does-calf sharing is on a rotational basis. If this sharing arrangement is adopted under harsh environmental conditions such as low rainfall and consequent scarcity of feed, as occurs in the Guinea and Sudan savannahs, a party can easily lose his share of calves and have his gain eroded. We interpret the occasional reward of the kraal owner with an animal that occurs under implicit contracts as a way of circumventing a possible loss of his share. Calves are accumulated and reared for a period of time, and the cattle owner then rewards the kraal owner out of those that survived. Hence, in contrast to rotational sharing as pertains in the Coastal savannah, we see the occasional rewards of animals, after several periods, under implicit contracts as a form of remuneration where parties implicitly insure themselves against severe environmental losses. Problems of mutual trust are solved by the long-term nature of the relationship between the parties.

Again, the Sudan and Guinea savannahs have the majority of subsidy-only contracts and some fixed-wage contracts. These contract types require that cattle owners who are providing subsidies are able to monitor their use by kraal owners. The cost of alternative use of cattle owner's time in the Guinea and Sudan savannahs is likely to be lower in the Guinea and Sudan savannahs than in the Transitional and Coastal savannahs. A large portion of the Coastal savannah is in the Greater Accra Region which hosts the capital of Ghana and has other large towns. Urbanisation and economic opportunities are greater in the Coastal savannah than in the 
Transitional zone (G.S.S. 2014). Fixed-wage contracts did not occur in the Coastal savannah at all. This could also be explained by the cattle owner's ability to monitor. Paying fixed wages means that the cattle owner needs to be sure that the kraal owner puts in his best efforts. In the Coastal savannah, cost of monitoring is arguably the highest making the choice of fixed-wage contracts unlikely. This agrees with Binswanger and McIntire (1987) who observe that an animal owner will opt for wage labour only if he can supervise the care given to his animals.

Similarly, outside options for cattle owners in the Coastal savannah is greater than in the Transitional zone. Hence, cattle owner's cost of monitoring kraal owners is less in the Transitional zone than in the Coastal savannah. The higher the cattle owner's cost of monitoring, the lower his share of calves and the higher the share of calves received by kraal owners. Accordingly, we find that in the Transitional zone, cattle owners do more monitoring and receive a higher share of calves; hence, kraal owners receive less share (one third) of cattle than their counterparts in the Coastal savannah (one half). It also agrees with the result that the proportion of share contracts where the cattle owner provides subsidy for labour and veterinary care inputs, which are major components of inputs, is higher in the Transitional zone than in the Coastal savannah. The observation that higher input contribution goes with receipt of higher output share is in line with Bardhan and Rudra (1980).

Most cattle owner-kraal owner contracts have a long duration which stems largely from the form of remuneration for kraal owners. For instance, an indefinite duration of contracts facilitates the feasibility of calf sharing contracts. First, it makes the rotational sharing arrangement feasible. A cow calves for the first time after approximately 3 years, and the calving interval could be as high as 3 years. Hence, if each party is to have his turn at getting his share of output, then the contract duration must be long. If the kraal owner is entitled to the third calf, and not the second, then he must wait even longer. If they are to have multiple turns at sharing output from the same cow, then the duration must be even much longer. Second, it reduces the moral hazard in the arrangement. Since sharing of output is repeated, there is opportunity to punish a party that deviates from the terms of the contract. Binswanger and McIntire (1987) noted that cattle owner-kraal owner contracts were prone to moral hazard and potential theft problems; therefore, these contracts should be of a long-term nature. Turner and Hiernaux (2008) also found that entrustments were generally made for an indefinite period of time and that entrustments of animals were much more common with cattle than small stock.

\section{Characteristics kraal owner-herdsman contracts}

The prominent feature of cow milk being used for herdsman remuneration agrees with findings of other studies. Toulmin (1992) found that the herdsman had complete entitlement to milk; however, this was only on specific days of the week while the kraal owner was entitled to milk for the rest of the days. Hill (1964) observed that normally in the Accra Plains (which is a large part of the Coastal savannah), herdsmen's only remuneration was the milk collected from the herd. Payment with milk is also consistent with observations by earlier studies (Turner and Hiernaux 2008; Turner 1999; Toulmin 1992; Moritz et al. 2011; Tonah 2003, 2006).

Compensation with milk did not mean complete absence of fixed payments like animals, food, and clothes. This agrees with observations by Dijk (1994). van Driel (1999) also observed that the form of compensation for herdsmen in northern Benin included part of the milk harvest and offspring. He further noted that the portion of milk given to the herdsman varied across regions. In other specified contracts, the herdsman got no milk but only a fixed payment in kind or cash. The few instances where the herdsman was not rewarded in any form was associated more with the use of family labour for herding than hired labour.

Unlike cattle owner-kraal owner contracts, a substantial proportion of contracts between kraal owner and herdsman had fixed duration. For instance, contracts in which the herdsman received a heifer as a reward at the end of a contract period were found especially in the Coastal savannah. These contracts also had a fixed duration. Here, the herdsman could leave the herding business and get back to school or find some other employment, or extend his contract for another period. The heifer could be considered as a start-up capital for the young herdsman to begin his own cattle business.

In all studied regions, there were cases where the contracts had no fixed duration. In these cases, the herdsmen considered herding as a long-term employment, perhaps a way of life. This could have been due to fewer alternative employment avenues for them. This is especially true for herdsmen who belong to the Fulani ethnic group. Dijk (1994) and Turner and Hiernaux (2008), who studied herding arrangements among the Fulbe or Fulani in West Africa, observed that herding contracts could be longlasting or indefinite. Most members of the Fulani ethnic group have specialised skills in herding cattle and virtually depend on animals for their livelihood. In other parts of West Africa, especially in the Sahel zone, herdsmen were hired on short-term bases for periods of about 6 months to look after transhumant herds (Bassett 1994). Only few contracts were found that had a fixed duration of less than 1 year. This could be because the cattle herds in Ghana, as such the sub-humid zone, are mostly sedentary herds. 


\section{Drivers of kraal owner-herdsman contract}

Payment of herdsmen with milk was associated more with hired herdsmen than with familial herdsmen, whereas it was the other way around with non-milk fixed payments. These differences in remuneration are explained based on transaction cost theory with agency theory providing additional depth in some instances.

The key transaction engaged in by kraal owners and herdsmen is the exchange of the latter's labour for pay. Inherent to this relationship is moral hazard. This is particularly the case when hired labour is used for herding as opposed to family labour. According to Holmstrom and Milgrom (1991), when performance is not easily measured and the agent owns returns to the asset, he should be incentivised such that he is not too cautious with the use of the asset. Extending this to cattle, we note that it is difficult to measure or verify the quantity of milk harvested from cattle accurately, since only partial milking is done. Partial milking means that the herdsman is expected to leave some milk in the cows for calves to suckle. The kraal owner can allow the hired herdsman to keep a high proportion of milk harvested or the entire harvest from cows as his remuneration. The herdsman's entitlement to milk makes him employ his best skills to herd cattle to obtain adequate nutrition, because the better the nutrition of cattle, the better their reproductive performance and milk output. Having ensured that cattle have adequate nutrition, the herdsman is not cautious about extracting milk from the animals as there are sufficient quantities to meet his needs without detrimental consequences for cows and calves. However, if the kraal owner pays the herdsman cash in lieu of milk, when opportunity exists for herdsmen to harvest the milk, the kraal owner cannot stop him since it is costly to monitor them.

The occasional cash and food provisions to a herdsman who has entitlements to milk often result from feed scarcity due to adverse environmental conditions. Under such situations, the kraal owner supplements milk remuneration with cash or food.

Non-milk fixed payments were associated with the use of family labour for herding. We remarked that family labour is probably associated less with moral hazard than is hired labour. Consequently, it is less likely that a familial herdsman will secretly harvest milk from cows or engage in over-harvesting of milk with detrimental consequences for cow and calves. Hence, the kraal owner can keep the milk for himself and feeding of calves and offer low-powered incentive payments to the herdsman. This could explain why herdsmen who are family members receive non-milk fixed payments such as animals. These herdsmen could have access to milk because they are part of the family; however, the volumes will be smaller compared to what they would have got if they had a milk payment contract.
The predominance of fixed duration kraal ownerherdsman contract in the Coastal and Transitional zones coincides with the predominance of explicit contracts in the two agro-ecological zones. This suggests that contracts are more formal in the two zones. The administrative regions constituting these zones are more urbanised than regions in the Guinea and Sudan savannahs. This means that transactions in the Coastal and Transitional zones are carried out with less informality.

Our study throws more light on the features of contracts in cattle production which pertain to obligations of parties and compensations they receive for performing their duties. Also, the study contributes to the strand of the literature that focuses on explanations for variations in contracts or the choice of one contract over another. We have found that the transaction cost theory helps explain the variations in contract types. Transaction cost is embodied in features of zones. Thus, constraints posed by these features of the environment could be reduced thereby reducing transaction cost associated with them. If reduction in transaction cost promotes the choice of contract types that enhance efficiency and productivity, these outcomes will be improved.

\section{Conclusion}

The objectives of this study have been to ascertain the nature of contracts in cattle production in Ghana and to explain existing contract types. We found two categories of contracts: cattle owner-kraal owner contracts and kraal owner-herdsman contracts. Each category could be grouped into explicit contracts, in which the remunerations of parties are explicitly specified, and implicit contracts, in which remunerations are not explicitly specified. Explicit cattle owner contracts comprised share contracts under which the cattle owner gives a share of calves to the kraal owner, subsidy-only contracts under which the cattle owner only compensates the kraal owner for expenses incurred on the former's cattle, and fixed-wage contracts under which the cattle owner pays the kraal owner a fixed wage in cash or kind. Explicit kraal owner-herdsman contracts comprised milk payment and non-milk payment contracts. We explained these findings with agency and transaction cost theory.

Features of agro-ecological zones tended to shape contracts. These features had implications for transaction cost. For instance, the predominance of implicit contracts in zones with single rainfall peaks, and therefore a long dry season and high environmental uncertainty (Guinea and Sudan savannahs), was explained by the high cost kraal owners incur when a calf dies, due to feed scarcity, and the opportunity to share this risk with the cattle owner. Further, the occurrence of subsidy-only contracts and fixed-wage payments in particular zones was explained by the lower cost of monitoring associated 
with such zones. The association of hired herdsmen with milk payment and familial herdsmen with non-milk payment contracts was explained by opportunistic behaviour of herdsmen and difficulty of measuring performance.

Our explanations for the variations in contract types with zones are more suggestive than definitive, since we are unable to go beyond the establishment of associations to causality. In the subsequent studies, we will use more rigorous methods to verify the drivers of some contract types. The transaction cost theory explains most aspects of the different contract types. Knowledge of these drivers and how they influence incentives can provide information for policy formulation aimed at improving the incentives for productivity-enhancing input use and investment in cattle production. Ultimately, this can lead to increased output of meat, milk, and other livestock products and thereby meet the growing demand for livestock products.

The study is limited in a few ways. Further insights into the contract characteristics could have been obtained by exploring the relationship between implicit contracts and subsidy-only contracts on one hand and social relations and kinship between parties on the other. Thus, it is not possible to comment on this aspect of implicit contracts in the current study. A combination of quantitative and qualitative approach could also have thrown more light on several aspects of contract types. However, in the current study, one of the main aims was to establish the prevalence and distribution of contract types across the country.

Future studies could extend this study by exploring the connection between social and kinship relations and implicit and subsidy-only contracts, and possible correlations between cattle owner-kraal owner contracts and kraal owner-herdsman contracts.

\section{Appendix}

Table 7 Study locations

\begin{tabular}{ll}
\hline Agro-ecological zone & Districts \\
\hline Coastal savannah & Ningo Prampram \\
& South Tongu \\
& Ada West \\
Guinea savannah & Saboba \\
& Wa West \\
& Wa Municipal \\
Sudan savannah & Garu-Tempane \\
Transitional zone & Pusiga \\
& Atebubu-Amantin \\
& Ejura-Sekyere \\
& Kintampo North \\
\hline
\end{tabular}

Source: field data

\section{Abbreviations}

ARI: Animal Research Institute; GSS: Ghana Statistical Service; IBM: International Business Machines; MOFA: Ministry of Food and Agriculture; SPSS: Statistical Package for Social Sciences; FAO: Food and Agriculture Organization

\section{Acknowledgements}

We are grateful to the agricultural officers in all the study districts who helped to collect the data for this study. We are also grateful to friends and colleagues who offered suggestions for improving the earlier versions of this paper. Our thanks also go to the anonymous reviewers who made suggestions for the improvement of this paper.

\section{Authors' contributions}

GA conceived the idea for this study, coordinated the data collection, analysed and interpreted the data, and wrote the first draft of the manuscript. RH was a major contributor to refining the project idea, interpretation of the data, and manuscript writing. NK and AK contributed to the preparation of data collection instruments and manuscript writing. All authors read and approved the final manuscript.

\section{Funding}

The research described in this paper was financially supported by the Wageningen University Sandwich PhD Fellowship and the West Africa Agriculture Productivity Improvement Programme (WAAPP 2) PhD fellowship.

\section{Availability of data and materials}

The dataset generated and or analysed during the current study are available in Mendeley data https://doi.org/10.17632/fwzkzm423x.1 (DOI is reserved but not active).

\section{Ethics approval and consent to participate}

NA

\section{Consent for publication}

NA

\section{Competing interests}

The authors declare that they have no competing interests.

\section{Author details}

'Development Economics Group, Wageningen University, Hollandesweg 1, 6706 KN Wageningen, the Netherlands. ${ }^{2}$ Council for Scientific \& Industrial Research (CSIR) - Animal Research Institute, P.O. Box AH2O, Accra, Ghana. ${ }^{3}$ Department of Agricultural Economics and Agribusiness, University of Ghana, P.O. Box LG 25, Legon, Accra, Ghana.

Received: 20 May 2019 Accepted: 6 May 2020

Published online: 30 June 2020

\section{References}

Abdulai, Awudu, Victor Owusu, and Renan Goetz. 2011. Land tenure differences and investment in land improvement measures: Theoretical and empirical analyses. Journal of Development Economics 96 (1): 66-78.

Ackerberg, D.A., and M. Botticini. 2002. Endogenous matching and the empirical. determinants of contract form. Journal of Political Economy 110 (3): 564-591.

Allen, F. 1985. On the fixed nature of sharecropping contracts. The Economic Journal 95: 30-48.

Baker, G., R. Gibbons, and Kelvin J. Murphy. 2002. Relational contracts and the theory of the firm. Quarterly Journal of Economics 117 (1): 39-84. https://doi. org/10.1162/003355302753399445.

Baker, George, Robert Gibbons, and Kevin J. Murphy. 1997. Implicit contracts and the theory of the firm. Cambridge: National Bureau of Economic Research. NBER Working Paper No. 6177.

Bardhan, Pranab, and Ashok Rudra. 1980. Terms and conditions of sharecropping contracts: An analysis of village survey data in India. The Journal of Development Studies 16 (3): 287-302.

Barzel, Yoram. 1982. Measurement cost and the organization of markets. The Journal of Law and Economics 25 (1): 27-48. 
Bassett, Thomas J. 1994. Hired herders and herd management in Fulani pastoralism (northern Côte d'Ivoire) (Bergers salariés et gestion du troupeau chez les éleveurs peuls du Nord de la Cote-d'Ivoire). Cahiers d'études africaines 1: 147-173.

Basu, Kaushik. 1992. Limited liability and the existence of share tenancy. Journal of Development Economics 38 (1): 203-220.

Binswanger, H.P., and J. McIntire. 1987. Behavioral and material determinants of production relations in land-abundant tropical agriculture. Economic Development and Cultural Change 36 (1): 73-99.

Braverman, Avishay, and Joseph E. Stiglitz. 1986. Cost-sharing arrangements under sharecropping: Moral hazard, incentive flexibility, and risk. American Journal of Agricultural Economics 68 (3): 642-652.

Dahlman, Carl J. 1979. The problem of externality. The Journal of Law and Economics 22 (1): 141-162.

Dijk, J.W.M. 1994. Livestock transfers and social security in Fulbe society in the Hayre, Central Mali. Foccal 22 (23): 97-112.

Eswaran, Mukesh, and Ashok Kotwal. 1985. A theory of contractual structure in agriculture. The American Economic Review 75: 352-367.

G.S.S. 2014. 2010 Population and Housing Census Report - Urbanisation. Accra: Ghana Statistical Service.

Ghatak, Maitreesh, and Priyanka Pandey. 2000. Contract choice in agriculture with joint moral hazard in effort and risk. Journal of Development Economics 63 (2) 303-326.

Goldstein, M., and C. Udry. 2008. The profits of power: Land rights and agricultural investment in Ghana. Journal of Political Economy 116 (6): 9811022.

Grossman, Sanford J., and Oliver D. Hart. 1983. An analysis of the principal-agent problem. Econometrica: Journal of the Econometric Society 1: 7-45.

GSS. 2014. Ghana Living Standards Suvey Round 6 (GLSS 6). Accra: Ghana Statistical Service (G.S.S)

GSS. 2015. Revised 2014 annual gross domestic product. Accra: Ghana Statistical Service (GSS).

Hallagan, William. 1978. Self-selection by contractual choice and the theory of sharecropping. The Bell Journal of Economics 1: 344-354

Hill, P. 1964. A socio-economic report on cattle ownership and Fulani herdsmen in the Ashaiman/Dodowa district of the Accra Plains. Ghana: Institute of African Studies, University of Ghana mimeo.

Hill, Polly. 1970. Studies in rural capitalism in West Africa: Cambridge University Press.

Hölmstrom, Bengt. 1979. Moral hazard and observability. The Bell Journal of Economics 10: 74-91.

Holmstrom, Bengt, and Paul Milgrom. 1991. Multitask principal-agent analyses: Incentive contracts, asset ownership, and job design. Journal of Law, Economics, and Organization 7: 24-52.

Jacoby, H.G., and G. Mansuri. 2009. Incentives, supervision, and sharecropper productivity. Journal of Development Economics 88 (2): 232-241.

Jahnke, Hans E. 1982. Livestock production systems and livestock development in tropical Africa. Vol. 35. Kiel: Kieler Wissenschaftsverlag Vauk Kiel.

Kim, Jongwook, and Joseph T. Mahoney. 2005. Property rights theory, transaction costs theory, and agency theory: An organizational economics approach to strategic management. Managerial and Decision Economics 26 (4): 223-242.

Laffont, J.J., and M.S. Matoussi. 1995. Moral hazard, financial constraints and sharecropping in El Oulja. The Review of Economic Studies 62 (3): 381-399.

Laffont, Jean-Jacques, and David Martimort. 2009. The theory of incentives: The principal-agent model: New Jersey: Princeton University Press.

MOFA. 2016. Ghana livestock development policy strategy. Accra: Ministry of Food and Agriculture (MOFA)

Moritz, Mark. 2010. Understanding herder-farmer conflicts in West Africa: Outline of a processual approach. Human Organization 69 (2): 138-148.

Moritz, Mark, Sara Handa, Yu-Jen Chen, and Ningchuan Xiao. 2015. Herding contracts and pastoral mobility in the Far North region of Cameroon. Human Ecology 43 (1): 141-151.

Moritz, Mark, Kristen Ritchey, and Saïdou Kari. 2011. The social context of herding contracts in the Far North region of Cameroon. The Journal of Modern African Studies 49 (02): 263-285. https://doi.org/10.1017/S0022278X11000048.

Moyo, S., and F.J.C. Swanepoel. 2010. Multifunctionality of livestock in developing communities. In The role of livestock in developing communities: Enhancing multifunctionality, ed. A. Stoebel F. Swanepoel and S. Moyo. Wageningen: $\mathrm{CTA}$

Muthoo, Abhinay. 1998. Renegotiation-proof tenurial contracts as screening mechanisms. Journal of Development Economics 56 (1): 1-26.
Newbery, David M.G. 1977. Risk sharing, sharecropping and uncertain labour markets. The Review of Economic Studies 44 (3): 585-594.

Okantah, S.A., F.Y. Obese, E.O.K. Oddoye, P. Gyawu, and Y. Asante. 1999. A survey on livestock and milk production characteristics of peri-urban agropastoral dairying in Ghana. Gh. J. Agric. Sci 32: 39-46.

Omore, A., S.J. Staal, E.L.K. Osafo, L. Kurwijilla, D. Barton, N. Mdoe, G. Nurah, and G. Aning. 2004. Market mechanisms, efficiency, processing and public health risks in peri-urban dairy product markets: Synthesis of findings from Ghana and Tanzania. Nairobi: International Livestock Research Institute.

Oppong-Anane, K., N. Karbo, C.K. Doku, J.S. Dittoh, H. Bayor, S.W.A. Rhule, G.Y. Ameleke, and E.T. Sottie. 2008. Ghana's livestock growth trend. Ministry of Food and Agriculture (MOFA): Accra.

Otchere, E., and S. Okantah. 2001. Smallholder dairy production and marketing in Ghana. In Smallholder dairy production and marketing: Opportunities and constraints. India: Anand.

Otchere, E.O., N. Karbo, and J. Bruce. 1997. Cattle rearing in the northern region of Ghana: a case study. Paper presented during the study visit of animal production systems in the humid and subhumid zones in Western and Central Africa, Guinea, 3-14 November 1997. Achimota: Animal Research Institute (ARI).

Place, Frank, and Peter Hazell. 1993. Productivity effects of indigenous land tenure systems in Sub-Saharan Africa. American Journal of Agricultural Economics 75 (1): 10-19.

Reid, Joseph D. 1976. Sharecropping and agricultural uncertainty. Economic Development and Cultural Change 24: 549-576.

Sen, D. 2011. A theory of sharecropping: The role of price behavior and imperfect competition. Journal of Economic Behavior and Organization 80 (1): 181-199.

Shaban, R.A. 1987. Testing between competing models of sharecropping. The Journal of Political Economy 95 (5): 893-920.

Singh, N. 2000. Theories of sharecropping. In Readings in development economics, micro-theory, ed. Pranab Bardhan and Christopher Udry, 19-71. Cambridge and London: MIT Press.

Stiglitz, J.E. 1974. Incentives and risk sharing in sharecropping. The Review of Economic Studies 41: 219-255.

Tadesse, M.A., S.T. Holden, R.A. Øygard, and J. McPeak. 2016. Cattle sharing and rental contracts in an agrarian economy: Evidence from Ethiopia. Agricultural Economics (United Kingdom) 47 (5): 479-492. https:/doi.org/10.1111/agec.12248.

Tonah, Steve. 2003. Integration or exclusion of Fulbe pastoralists in West Africa: A comparative analysis of interethnic relations, state and local policies in Ghana and Côte d'Ivoire. The Journal of Modern African Studies 41 (01): 91-114. https://doi.org/10.1017/S0022278X02004160.

Tonah, Steve. 2006. Migration and farmer-herder conflicts in Ghana's Volta Basin. Canadian Journal of African Studies/Revue canadienne des études africaines 40 (1): 152-178. https://doi.org/10.1080/00083968.2006.10751339.

Toulmin, Camilla. 1992. Herding contracts: For better or worse. ILEIA Newsletter 8 (3): 8-9.

Turner, M.D. 2009. Capital on the move: The changing relation between livestock and labor in Mali, West Africa. Geoforum 40 (5): 746-755.

Turner, Matthew D. 1999. Labor process and the environment: The effects of labor availability and compensation on the quality of herding in the Sahel. Human Ecology 27 (2): 267-296.

Turner, Matthew D., and Pierre Hiernaux. 2008. Changing access to labor, pastures, and knowledge: The extensification of grazing management in Sudano-Sahelian West Africa. Human Ecology 36 (1): 59-80. https://doi.org/10. 1007/s10745-007-9149-y.

Driel, Antje van. 1999. "The end of the herding contract decreasing complementary linkages between Fulbe pastoralists and Dendi agriculturalists in northern Benin." In Pastoralists under pressure: Fulbe societies confronting change in West Africa, edited by V. Azarya J.W.M. van Dijk, A. Breedveld, and M.E. de Bruijn, 191-210. Leiden: Brill.

Williamson, O.E. 1989. Chapter 3 Transaction cost economics. In Handbook of industrial organization.

Williamson, O.E. 2000. The new institutional economics: Taking stock, looking ahead. Journal of Economic Literature 38 (3): 595-613.

Zhang, Daowei, and Eric Aboagye Owiredu. 2007. Land tenure, market, and the establishment of forest plantations in Ghana. Forest Policy and Economics 9 (6): 602-610. https://doi.org/10.1016/j.forpol.2005.12.001.

\section{Publisher's Note}

Springer Nature remains neutral with regard to jurisdictional claims in published maps and institutional affiliations. 